\title{
Picking Up the Reigns
}

Citation for published version (APA):

Massar, K., Nübold, A., van Doorn, R. R. A., \& Schelleman - Offermans, K. (2020). Picking Up the Reigns: The Crucial Role of Psychological Capital in the Transition from Long-Term Unemployment to Entrepreneurship. In P. L. Perrewé, P. D. Harms, \& C-H. Chang (Eds.), Entrepreneurial and Small Business Stressors, Experienced Stress, and Well-Being (Vol. 18, pp. 147-170). Emerald Group Publishing Limited. Research in Occupational Stress and Well Being Vol. 18 https://doi.org/10.1108/S1479-355520200000018007

Document status and date:

Published: 08/08/2020

DOI:

10.1108/S1479-355520200000018007

Document Version:

Publisher's PDF, also known as Version of record

\section{Document license:}

Taverne

\section{Please check the document version of this publication:}

- A submitted manuscript is the version of the article upon submission and before peer-review. There can be important differences between the submitted version and the official published version of record.

People interested in the research are advised to contact the author for the final version of the publication, or visit the DOI to the publisher's website.

- The final author version and the galley proof are versions of the publication after peer review.

- The final published version features the final layout of the paper including the volume, issue and page numbers.

Link to publication

\footnotetext{
General rights rights.

- You may freely distribute the URL identifying the publication in the public portal. please follow below link for the End User Agreement:

www.umlib.nl/taverne-license

Take down policy

If you believe that this document breaches copyright please contact us at:

repository@maastrichtuniversity.nl

providing details and we will investigate your claim.
}

Copyright and moral rights for the publications made accessible in the public portal are retained by the authors and/or other copyright owners and it is a condition of accessing publications that users recognise and abide by the legal requirements associated with these

- Users may download and print one copy of any publication from the public portal for the purpose of private study or research.

- You may not further distribute the material or use it for any profit-making activity or commercial gain

If the publication is distributed under the terms of Article $25 \mathrm{fa}$ of the Dutch Copyright Act, indicated by the "Taverne" license above, 


\title{
CHAPTER 6
}

\section{PICKING UP THE REIGNS:}

\author{
THE CRUCIAL ROLE OF
}

PSYCHOLOGICAL CAPITAL

IN THE TRANSITION FROM

LONG-TERM UNEMPLOYMENT

TO ENTREPRENEURSHIP

\author{
Karlijn Massar, Annika Nübold, Robert van Doorn \\ and Karen Schelleman-Offermans
}

\begin{abstract}
There is an abundance of empirical evidence on the positive effects of employment - and the detrimental effects of unemployment - on individuals' psychological and physical health and well-being. In this chapter, the authors explore whether and how self-employment or entrepreneurship could be a solution for individuals' (re)entry to the job market and which (psychological) variables enhance the likelihood of entrepreneurial success. Specifically, the authors first focus on unemployment and its detrimental effects for health and wellbeing, and outline the existing interventions aimed at assisting reemployment and combating the negative consequences of unemployment for individuals' well-being. Then, the authors will explore entrepreneurship as a potential solution to unemployment and explore the psychological variables that enhance the likelihood of entrepreneurial success. One of the variables the authors highlight as particularly relevant for self-employment is the second-order
\end{abstract}

\footnotetext{
Entrepreneurial and Small Business Stressors, Experienced Stress, and Well-Being Research in Occupational Stress and Well-Being, Volume 18, 147-170

Copyright (C) 2020 by Emerald Publishing Limited

All rights of reproduction in any form reserved ISSN: 1479-3555/doi:10.1108/S1479-355520200000018007
} 
construct of Psychological Capital (PsyCap; Luthans, Avolio, Avey, \& Norman, 2007), as well as its individual components - hope, optimism, efficacy, and resilience. PsyCap is a malleable construct that can be successfully trained, and PsyCap interventions are inherently strength-based and have positive effects on employees' and entrepreneurs' performance and wellbeing. Therefore, the authors end the chapter by suggesting that a PsyCap component in existing education and training programs for entrepreneurship is likely to not only increase entrepreneurial intentions and success, but also increases participants' well-being, self-esteem, and the general confidence they can pick up the reigns and take back control over their (professional) lives.

Keywords: Unemployment; self-employment; entrepreneurship; Psychological Capital; entrepreneurship education and training; well-being

The United Nations have set "Decent work and economic growth" as the eighth of their 17 Sustainable Development Goals (SDGs) for 2030, and it entails

[...] opportunities for everyone to get work that is productive and delivers a fair income, security in the workplace and social protection for families, and better prospects for personal development and social integration. (Sustainable Development Knowledge Platform, 2019)

Global unemployment rates are currently at 5.2\% (OECD, 2019) and are slowly decreasing, but vary greatly between countries and educational levels. Unemployed people are those who report that they are without work, they are physically and psychologically able to work, and they have taken active steps to find work in the last four weeks. Globally, unemployment is regarded as an undesirable phenomenon, due to the detrimental consequences for individuals and society as a whole.

Conversely, there is evidence for positive effects of employment on well-being. There is a consensus in the literature that working has instrumental and expressive meaning for individuals, meaning that employment is seen as necessary to satisfy physical needs but is also directly linked to an individual's identity and social standing (e.g., Kuchinke, Ardichvili, Borchert, \& Rozanski, 2009). Jahoda's (1982) classical work identified five latent functions of work, which provide a sense of meaning and purpose to employment: time structure, collective purpose, social contacts, status, and activity. A study by Paul and Batinic (2010) confirmed that employed individuals, including unskilled manual workers, reported higher levels on Jehoda's latent functions than the unemployed and those out of the labor force (students, retirees). Furthermore, Law, Steinwender, and Leclair (1998) report that occupation has a positive influence on well-being and (mental) health, and Christiansen, Backman, Little, and Nguyen (1999) report how time spent engaging in meaningful occupation has a positive effect on individuals' well-being. Lastly, the social investment principle (e.g., Lodi-Smith \& Roberts, 2007) emphasizes that being able to invest in and commit to age-graded adult 
social roles that are part of normative development - such as the work role, or pursuit of a career - contributes to identity formation and identity clarity, and stimulates general well-being (see also Greenberger \& O’Neill, 1993).

Thus, there is empirical evidence on the positive effects of employment, as well as the detrimental effects of unemployment, on individuals' psychological and physical health and well-being (McKee-Ryan, Song, Wanberg, \& Kinicki, 2005; Paul \& Moser, 2009). However, the existing research on how to best combat and reduce unemployment and its negative impact is still lacking rigor and coherence. Generally, countries try to reduce unemployment rates by developing and implementing governmental policies and programs that either target the detrimental consequences of unemployment (e.g., a focus on decreasing psychological complaints), or the unemployment itself (e.g., via training of more effective job search behavior; for an overview see Moore et al., 2017). However, the effects of these policies and programs are often only moderate in size (Paul \& Moser, 2009), and often lack sustainability in the face of economic fluctuations. One particular intervention type that does seem to show more long-lasting effects, leading to sustainable (re)entry to the labor market, concerns programs that promote selfemployment, that is, entrepreneurship (Dvouletý \& Lukeš, 2016; Michaelides \& Benus, 2012).

In the current chapter, we will therefore explore how self-employment may be one solution for individuals' (re)entry to the job market, and which (psychological) variables are crucial in entrepreneurial success. Specifically, we will first focus on unemployment, summarize its detrimental effects, and outline the types of interventions that have been set up to aid reemployment or to combat the negative consequences for individuals' well-being. Then, we will explore entrepreneurship as a potential solution to unemployment and highlight the role of Psychological Capital (PsyCap; Luthans, Avolio et al., 2007) in the context of entrepreneurship and its positive consequences for self-employed individuals. Research has shown that PsyCap is a malleable construct which can be successfully trained (Luthans, Youssef, \& Avolio, 2007; Luthans et al., 2008), which contributes to the success and life satisfaction of entrepreneurs (Baluku, Kikooma, \& Kibanja, 2016; Bockorny \& Youssef-Morgan, 2019; Hmieleski \& Carr, 2008). Thus, in the last part of the chapter, we suggest that incorporating a PsyCap component in existing education and training programs for entrepreneurship might strengthen the success of such programs, as well as the entrepreneurial success of its participants.

\section{UNEMPLOYMENT}

\section{Consequences of Unemployment}

"Would you continue to work if you won the lottery?" The responses to this question may well illustrate the psychological value of work for most individuals. In addition to the positive effects of being employed for well-being, there is also compelling evidence that people who are unemployed largely lack aspects such as 
structure, meaning and purpose, social contacts, status, and activity (e.g., Jahoda, 1982 ) in their lives, and as a consequence suffer from distress and impaired wellbeing (Paul \& Batinic, 2010; Selenko, Batinic, \& Paul, 2011). The detrimental effects of unemployment in their turn affect a wide range of psychological and physiological well-being estimators, ranging from depressed mood to high blood pressure (McKee-Ryan et al., 2005). Indeed, unemployment or involuntary job loss can be considered a critical life event with long-lasting negative impacts on life satisfaction (Lucas, Clark, Georgellis, \& Diener, 2004). Especially the long-term unemployed (i.e., those being unemployed for one year or longer; International Labour Office, 2015) show strong impairments of well-being when being compared to short-term unemployed (McKee-Ryan et al., 2005).

Research further indicates that such impairments are often long-term and that many people never fully recover from unemployment. For example, in a 15 -year longitudinal study, Lucas et al. (2004) demonstrate that people who experienced unemployment did not fully return to their former levels of life satisfaction over time, even after becoming reemployed. Furthermore, this study showed that people did not become less sensitive to experiences of unemployment if they had previously experienced unemployment, a finding also supported by Paul and Moser (2009). Additionally, Paul and Moser (2009) as well as McKee-Ryan et al. (2005) provide meta-analytic evidence for effects regarding individuals' age and the duration of unemployment. These studies confirm that in particular the longterm unemployed as well as younger people suffer more from unemployment than short-term unemployed and middle aged (Paul \& Moser, 2009) or older people (McKee-Ryan et al., 2005). In addition, particularly youth unemployment has been shown to have long-term adverse - "scarring" - health consequences later in life, both mentally and physically (Hammarström \& Janlert, 2002; Strandh, Winefield, Nilsson, \& Hammarström, 2014).

\section{Existing Interventions Aimed at Coping with or Escaping Unemployment}

Interventions that target unemployed individuals with the aim of trying to aid reemployment or mitigate the effect of job loss on mental health are an important part of governmental actions to combat unemployment. In general, these interventions aim to help the unemployed to build up important resources, either by (1) changing negative attitudes or (self-) appraisals and increasing effective coping strategies, (2) improving job search skills, or (3) both. As summarized by Moore et al. (2017), specific examples include interventions that build up job search skills and resilience to application rejections, provide advice to help people access governmental support, and aim to reduce psychological strain and increasing life satisfaction. These latter programs often make use of cognitive behavioral therapy or emotional competency training.

Interventions that have successfully reduced the detrimental effects of unemployment on well-being have, for example, mimicked the positive psychological and social environment of paid work, by giving unemployed people the chance to collaborate, build up routines, and make use of their skills (i.e., work experience schemes; see Sage, 2019). In these interventions, in particular the structured 
use of time, one of the latent benefits in Jahoda's model (1982), has been shown to improve mental health in unemployed people (McKee-Ryan et al., 2005). Furthermore, research has evidenced that being able to use psychological resources such as positive self-evaluations, or positive expectations for future reemployment are related to higher wellbeing and may significantly lower the detrimental effect of unemployment on individuals (McKee-Ryan et al., 2005). Job search programs - also called "job club" interventions - that focus on helping individuals to improve their job seeking behavior, like the JOBS program in the United States (Vinokur, Price, \& Schul, 1995; Vinokur \& Schul, 1997; Vinokur, van Ryn, Gramlich, \& Price, 1991) and the Työhön program in Finland (Vuori \& Vesalainen, 1999), effectively lower depression.

Nonetheless, even though some interventions thus may effectively prevent mental health deterioration or even improve it, current employment support approaches aimed at sustainable re-employment are still largely unevaluated and under-examined (Whelan, McGilloway, Murphy, \& McGuinness, 2018). Particularly, more research is needed to better understand the short- versus longterm effects of job search interventions, since the evidence in the literature is mixed. For example, in their meta-analysis, McKee-Ryan et al. (2005) have found that actively engaging in job search activities is related to lower mental health for unemployed workers, due to the high stress that is experienced while looking for a job and facing rejections. However, other studies reported that job search behavior is positively related to reemployment and the number of job offers received (Kanfer, Wanberg, \& Kantrowitz, 2001). Thus, these studies suggest that even though job search behavior may impair mental health in the short term, but may be beneficial on the long term.

Another aspect to consider more thoroughly in future research is the quality of reemployment. Reemployment per se may not be very indicative of the mental well-being of the formerly unemployed and his/her satisfaction with the newly acquired job (McKee-Ryan et al., 2005). As mentioned by the International Labour Office (2018), particularly in countries where there is no sufficient social safety net (e.g., unemployment insurance) individuals cannot afford to be unemployed and are thus forced to take on poorer quality jobs in terms of wages, organizational level, or skill utilization. This form of underemployment is associated with lower job satisfaction, work commitment, life satisfaction, and psychological well-being, due to the "relative deprivation" it evokes in individuals (Feldman, 1996; Feldman, Leana, \& Bolino, 2002).

Here, we suggest that one potential sustainable means to help individuals reenter the labor market and obtain suitable and adequate jobs are self-employment trainings. Those trainings support aspiring entrepreneurs to gain knowledge about the ins and outs of starting a business and overcoming potential obstacles along the way (Michaelides \& Benus, 2012). Initial evidence suggests that such programs are effective in helping unemployed individuals to start their own business and to sustain self-employment (even years later; Dvouletý \& Lukeš, 2016; Michaelides \& Benus, 2012). Particularly for the long-term unemployed, the option of entrepreneurship may thus be a viable option to escape their current situation, and improve financial, mental, and physical well-being. 


\section{(FOSTERING) SELF-EMPLOYMENT}

A self-employed individual (entrepreneur) is often defined as an individual who creates a new firm or venture and assumes the responsibility for the independent ownership (Gartner, 1988). Individuals may aspire self-employment for a number of reasons, among which are gaining autonomy - entailing independence and freedom - or passion and challenge to provide a product or service. Other motivations are more economical in nature, and driven by a desire to gain income, wealth, or status; or the opportunity to escape low wages, (the threat of) unemployment, or poverty (Blanchflower \& Meyer, 1994). Thus, in general, two approaches are distinguished to understand entrepreneurship as a solution for unemployment, why individuals decide to become self-employed, and what the (potential) effects are of such self-employment: First, the economic view focuses on what the (macro-)economic benefits or costs self-employment are, including its relationship with unemployment rates (see e.g., Thurik, Carree, Van Stel, \& Audretsch, 2008). Second, the psychological view describes the entrepreneur as an individual, and explains the individual benefits and costs of becoming selfemployed. We will first briefly explore the economic view, and subsequently pursue the psychological view to specify the psychological benefits of self-employment, and detail which characteristics determine whether individuals will be (successful) entrepreneurs.

Based on this economical notion to self-employment, local governments and international organizations such as the International Labor Office (2018) have instigated policies and projects to stimulate self-employment. From this notion, self-employment is assumed to benefit a country's economy, since it is assumed that self-employed ventures are innovative and will generate new jobs and wealth. Such seed or start-up grants have been part of policy in Britain, France, Germany, the United States, Australia, as well as in developing countries in Asia and Africa, where government programs provide transfer payments, loans, and tax exemptions to unemployed business starters (Blanchflower \& Meyer, 1994). However, other researchers maintain that these perceptions about the benefits of self-employment are flawed because, contrary to common belief, the typical startup is not innovative, creates few jobs, and generates little wealth (Shane, 2009). Thus, although in the current chapter we propose that entrepreneurship may be a viable option to escape long-term unemployment, there are some drawbacks to consider.

First, individuals should be aware that being self-employed is thought to mainly have nonmonetary benefits, such as greater autonomy, broader skill utilization, and the possibility to pursue one's own ideas (Benz, 2009). Research indicates that in particular subsidized entrepreneurs are less likely to aspire business growth, often do not significantly contribute to employment creation and economic growth in their countries (Hessels, Van Gelderen, \& Thurik, 2008), and even underperform compared to regular ones (Dvouletý \& Lukeš, 2016). Second, the earned wages of the self-employed are often lower (around $80 \%$ of those in paid employment) especially for women, and entrepreneurs forego the acquisition and updating of relevant skills and training that are often offered in 
larger organizations. Self-employed individuals also miss opportunities of acquiring new knowledge about developments in the labor market. Third, ending selfemployment, either by choice or by business failure, and returning to the wage labor market at a same functional level is often disadvantageous and may entail a reduction in wages, as a failed self-entrepreneur is often perceived as lacking experience and training. However, for the majority of these drawbacks (as well as benefits), there is large variability depending on regionality (e.g., rural vs. urban start-ups), national economic circumstances (e.g., recession vs. boom) and individual differences (e.g., male vs. female entrepreneurship, age; see e.g., Dvouletý \& Lukeš, 2016).

Employing a strict economic viewpoint on entrepreneurship thus necessitates identifying start-ups that have a low probability of enhancing economic growth, and to discourage the formation of such enterprises. However, we want to stress that business growth is only one of a range of possible policy goals. Other goals such as skill acquisition are relevant as well, and including additional variables than merely the economical ones is therefore important to better inform policy recommendations. Simply put, in line with Minola, Criaco, and Obschonka (2016): whereas many studies have focused mainly on self-employment actions, they have tended to overlook these actions' antecedents. These antecedents include an individual's motivations or personality traits, and they predict not only entrepreneurial intentions and actions, but also growth and success (see also Rauch \& Frese, 2007). Thus, a psychological viewpoint, with a focus on demographic and individual antecedents, and on the personal benefits of self-employment, seems highly relevant in order to be able to explain why an individual becomes an entrepreneur and what is needed to make a successful entrepreneur.

\section{Fostering Self-employment Through Education and Training}

Start-up failures are quite substantial, with $20 \%$ failing in the first year, and up to $70 \%$ having failed by their 10th year (Bureau of Labor Statistics, 2016). Therefore, it is essential to know the factors that contribute to becoming selfemployed, and to understand what makes a successful self-employment venture (Wolff, Nivorozhkin, \& Bernhard, 2016). Research on entrepreneurial survival in Australia, the United States, and Europe was able to distinguish a limited number of factors that contributed to the success and sustainability of self-employment (e.g., Blanchflower \& Meyer, 1994; Dvouletý, 2018; Millán, Congregado, \& Román, 2012). For example, individuals choosing self-employment more often are employed rather than unemployed, more often have a higher education, and are more often middle-aged males. Moreover, one's family background - such as having a self-employed parent - and current financial situation, as well as previous income levels also important determinants for workers to become self-employed (e.g., Blanchflower \& Meyer, 1994; Dvouletý, 2018; Millán et al., 2012;).

However, many studies suggest that rather than a specific degree or education, a broad mixture of skills and a familiarity with the day-to-day experience of owning a business, are important for entrepreneurial success. This fits with the idea of the entrepreneur as "jacks-of-all-trades" (Lazear, 2004). Given the importance 
of experience and skills as contributing factors to becoming self-employed, and the fact that one can train them, governments have developed and implemented a range of programs consisting education about and training of the skills necessary to become self-employed (Blanchflower \& Meyer, 1994). Many of these programs, which can be classified as entrepreneurship education (EE; often targeting students) or entrepreneurship training (ET; often targeting potential or practicing entrepreneurs) focus on topics ranging from socio-emotional and management skills, to employability and implementation of innovations (Valerio, Parton, \& Robb, 2014). Specifically, ET is implemented to encourage (long-term) unemployed individuals, in particular youth, to both become aware of the possibility of self-employment as well as gain the necessary skills to take the step to become self-employed. Many, but not all, of these ET programs offer financial allowances or subsidies, which support the self-employed individual through an introductory phase, or allow them to cover initial investment costs (Valerio et al., 2014). Generally, these programs are effective in reintegrating unemployed individuals in the labor market, as well as with respect to employment and income outcomes for the participants in the long run (i.e., five years after start-up; Caliendo \& Künn, 2011).

One successful example of EE is the Swedish Junior Achievement Company Program (JACP; see Elert, Andersson, \& Wennberg, 2015). This program provides secondary school students with the experience of the whole life cycle of a company using the "learning-by-doing" approach: Every year, over 20,000 students set up, run, and evaluate their own JACP company, in which they produce and sell some type of physical product or service. Mentors and teachers supervise the students, and the program concludes by calculating the balance and results sheets of each JACP company, after which they are closed down. Elert et al. (2015) conducted a longitudinal study in which they followed mid-1990s JACP participants for up to 16 years after graduation. They showed that compared to individuals who did not follow the JACP program, the probability that JACP participants started their own company was $27-30 \%$ higher. Moreover, income from these firms was around $10 \%$ higher than entrepreneurial income of individuals who did not participate in JACP.

Entrepreneurship education and training (EET) are also regularly implemented in developing countries to stimulate individuals to avoid or to overcome unemployment. For example, in Nigeria the Entrepreneurship Development Program (Awogbenle \& Iwuamadi, 2010) attempts to prepare and stimulate selfemployment in youth, with the ultimate aim to create jobs and improve their livelihoods and economic independence. The focus is on acquiring skills, such as the ability to take initiative, and creatively seek out and identify opportunities. Furthermore, participants in the program are instructed how to develop budgets and project resource needs, and to communicate effectively with potential clients and promote oneself and one's ideas. However, as Awogbenle and Iwuamadi (2010) also note, trainees in this program also raise concerns about the availability of and access to the funds necessary to start a business. To overcome such financial barriers, some entrepreneurship training programs implement micro-grants or subsidies to help entrepreneurs start-up their business. For example, the Youth 
Opportunities Program (YOP; Blattman, Fiala, \& Martinez, 2014) in northern Uganda is a government program designed to help poor and unemployed adults become self-employed artisans. Young adults were invited to form groups and prepare proposals for how they would use a grant to receive training and start independent trades. Funds of about $\$ 382$ per person were randomly allocated to participants in these groups. Four years after the first implementation of the YOP, Blattman et al. (2014) evaluated the outcomes: compared to a control group of individuals who did not receive the grants, the treatment group had 38\% higher earnings and worked $17 \%$ more hours. Moreover, this group exhibited actions indicative of an entrepreneurial mindset, such as record keeping, registering their business, and paying taxes. Importantly, especially women who received financial support benefited: Compared to the control group, women's their income was $73 \%$ greater four years after receiving the grant, and considerably higher than the $29 \%$ increase among men.

To summarize, education and training programs aimed to stimulate entrepreneurial activity among various groups seem to be quite effective and range from secondary school and undergraduate students to (long-term) unemployed individuals, in various regions across the world. However, these programs aimed at increasing the knowledge and skills necessary for successful entrepreneurship are only partly responsible for decisions to enter into self-employment, and for business owners' performance and survival. In the following section, we will review which various psychological traits and characteristics (as well as the resulting behaviors) play a role in these processes.

\section{PSYCHOLOGICAL TRAITS RELEVANT TO SELF-EMPLOYMENT}

Self-determination theory may give a theoretical basis to explain the varied success of self-employed individuals. The theory describes the importance of the fulfillment of three basic needs - autonomy, relatedness, and competence. These needs are related to higher levels of motivation and performance, life satisfaction, and behavioral persistence (Ryan \& Deci, 2000). Briefly, these needs translate to a desire to control the outcome of one's actions and to achieve mastery (competence), the desire to be connected to, interact with, and care for others (relatedness), and the desire to be the causal agent of one's life (autonomy; Ryan \& Deci, 2000).

Applied to self-employed individuals, the literature shows that such individuals often report more positive attitudes toward independence and freedom (Sutanto \& Eliyana, 2014). Indeed, entrepreneurs often forego higher wages to achieve the psychological benefits of autonomy (Croson \& Minniti, 2012). A psychological perspective on entrepreneurial success thus suggests that in addition to economic indicators for the performance of a business, such as sales growth or growth in employees (e.g., Chandler \& Hanks, 1994), the success of a business could additionally be evaluated by including individual or psychological characteristics to evaluate business performance, such as personal satisfaction, work-life balance, 
innovation, or contributing to society (Gorgievski, Ascalon, \& Stephan, 2011; Razmus \& Laguna, 2018).

The need for autonomy is also central to the job demands-control model (Karasek \& Theorell, 1990), which directly links it to well-being. The model posits that two factors are central to employee well-being and health, namely job demand and job control. Job demand refers to pace, complexity and amount of work, whereas job control refers to one's decision authority or autonomy, and the range of skills used in the job. The model predicts that when individuals are employed in high-demand, low-control jobs, they experience elevated levels of stress, which is detrimental to their (occupational) well-being and health. Furthermore, the control one experiences over one's job can actually buffer the negative effects of high demands, because it allows employees to adjust their work demands to match with their abilities, needs, and circumstances (e.g., Wall, Jackson, Mullarkey, \& Parker, 1996). Self-employment entails having a large amount of control over one's job demands and should in that sense provide a buffer for stress and positively promote overall well-being. Indeed, Hessels, Rietveld, and Van der Zwan (2017) show that the self-employed report lower levels of stress than employees, and that this relationship is fully explained by perceptions of high job control.

Moreover, there are different phases in the entrepreneurial process or venture life cycle, and these different phases of the entrepreneurial process consist of various activities that need to be performed. Moreover, at each phase, entrepreneurs have various roles to fulfill (Baron, 2007; Korunka, Kessler, Hermann, \& Lueger, 2010): in the pre-launch phase, individuals perform activities such as developing a business plan, and possibly building an entrepreneurial team. Next, in the launch phase, the focus is on implementing the business plan and performing activities focused on the survival the new venture. In the post-launch phase the main activities consist of actually running the business and focusing on growth, maintenance, or maturation (Ming \& Zuguang, 2013). Thus, small business owners need to be able to function well in a variety of roles, and by definition they often operate in unstructured, changing conditions, being exposed to uncertainties in many domains.

Therefore, psychological characteristics are likely to be beneficial to entrepreneurial success and increase well-being because they foster the achievement of entrepreneurial goals, and function as resources one can rely on or fall back to when coping with adversities. Since the demands placed on individuals tend to change during the entrepreneurial process, the role of characteristics and skills deemed most important in the entrepreneurial process may also change over time (Baron, 2007; Korunka et al., 2010). The self-employed also have greater autonomy and control over these demands, and therefore the outcome of these periods of intense job demands does not necessarily have to undermine their well-being. Moreover, any experienced stress likely depends on the individual's skills set, circumstances, and content of the demands. Similarly, although it can be useful to differentiate between the characteristics that contribute to entrepreneurial intentions from those that contribute to entrepreneurial success, they tend to overlap considerably. In the following, we will briefly summarize the literature on the 
personality traits and characteristics that are associated with the task of running a business.

\section{Traits and Characteristics Relevant to Entrepreneurship (Success)}

Psychological traits relevant to entrepreneurship are generally divided into general personality factors, such as the Big Five, and personality characteristics relevant to the task of entrepreneurship, such as achievement motivation or risk aversion. The Big Five personality traits consist of neuroticism, extraversion, conscientiousness, agreeableness, and openness to experience. Previous meta-analytic research has shown that compared to managers, entrepreneurs show higher scores on conscientiousness and openness to experience, but lower on agreeableness and neuroticism (Zhao \& Seibert, 2006). Furthermore, conscientiousness, openness to experience, and extraversion have shown to be relevant in predicting entrepreneurial intention and performance (Zhao, Seibert, \& Lumpkin, 2010). Nevertheless, most studies investigating the role of the Big Five personality traits in entrepreneurial success have usually found rather small effects, which might indicate that these personality traits influence entrepreneurial success at a more distal level.

Entrepreneurs are thought to be "jacks-of-all-trades" (Lazear, 2004), and therefore, looking at the specific traits that match the task of entrepreneurship rather than relying on broad personality factors might be more informative and explain better why some individuals start their own business (and succeed), and others do not (see also Rauch \& Frese, 2007). Several factors help an individual in actually launching a business, and according to Baron (2007) these are recognizing opportunities, developing an intention to start a business, and accumulating the necessary resources for starting one. In addition, entrepreneurs often have to make decisions under uncertainty, and have to perform many different tasks, for example, leadership, marketing, or accounting. Thus, having a proactive personality can be an important predictor of venture success (Rauch \& Frese, 2007): These individuals want to change their environment, show initiative and take action, and persevere until they achieve the desired change (Crant, 1996). Also, courage, defined as a character strength that promotes the exercise of will to achieve goals, even when faced with setbacks (Peterson \& Seligman, 2004), is perceived as an important quality for entrepreneurial success and has been found to increase entrepreneurs' life satisfaction (Bockorny \& Youssef-Morgan, 2019).

Courage may be related to another trait often identified among entrepreneurs, that is, risk-taking tolerance. Risk-taking tolerance may also contribute to entrepreneurial success in the pre-launch as well as post-launch phases (Owens, Kirwan, Lounsbury, Levy, \& Gibson, 2013). Moreover, individuals who are less risk averse (or more risk tolerant) are more likely to benefit from entrepreneurship training, as well as individuals with a higher desire for autonomy (Fairlie \& Holleran, 2012). Interestingly, other researchers have shown that lower levels of risk aversion only seem to influence the decision to become self-employed among individuals coming out of regular employment, whereas this trait does not seem to influence the decisions of those starting a business out of unemployment (Caliendo, Fossen, \& Kritikos, 2009). 
In addition to environmental factors and personal characteristics that facilitate acting on opportunities, also goal commitment has shown to be important to succeed as an entrepreneur throughout entrepreneurial process (Przepiorka, 2017). Goal commitment is defined as the amount of effort, time, and energy contributed in a long-term perspective to goal achievement while unwilling to decrease the level of goal difficulty. Klein, Wesson, Hollenbeck, and Alge (1999) found that engagement in pursuing a goal enhances the probability of achieving that goal. Goal commitment and effectiveness in achieving goals, among other things, are affected by decision-related action orientation (Kuhl, 1994; Przepiorka, 2017), which is an indicator of an individuals' control strength. Having high levels of this trait tends to prevents procrastination, often increases effective planning, and therefore enables action initiation (Kuhl, 1994). These skills of effective decision-making seem to be especially important for potential entrepreneurs in the pre-launch phase compared with actual entrepreneurs in post-launch phases (Przepiorka, 2017).

To summarize, in general successful self-employed individuals thus seem to be characterized by having positive expectancies of people, problems, situations, and future possibilities. They give evidence of having high levels of adjustment and stability, and exhibit an ability to handle stress and pressure. Lastly, successful self-employed individuals tend to believe that career success is a result of one's efforts and actions rather than luck or fate showed a higher work satisfaction (Owens et al., 2013). These characteristics are, to an extent, captured by the construct of PsyCap - which consists of hope, efficacy, resilience, and optimism; and this suggests that self-employed individuals may benefit from having high levels of PsyCap. In the following section, we will review the literature on the role of the four components of PsyCap, as well as the second-order construct of PsyCap itself, in entrepreneurship intentions and success.

\title{
OPTIMISM, EFFICACY, HOPE, AND RESILIENCE: PSYCHOLOGICAL CAPITAL AND SELF-EMPLOYMENT
}

\author{
Optimism, (Self-)efficacy, Hope, and Resilience
}

Before reviewing literature about the role of the second-order construct of PsyCap in entrepreneurship, we will focus on each individual component. First, optimism: Optimistic individuals are those who expect that they will be able to achieve successful outcomes, take active and constructive steps toward solving problems, and are persistent in their goal pursuit (e.g., Scheier, Carver, \& Bridges, 2001) - traits that inherently fit with entrepreneurship. Indeed, research consistently shows a strong association between (financial) optimism and self-employment (e.g., Cooper, Woo, \& Dunkelberg, 1988; Fraser \& Greene, 2006). The relationship between optimism and self-employment seems to be bi-directional: Not only are self-employed individuals more optimistic than employees (e.g., Koudstaal, Sloof, \& Van Praag, 2015), optimistic individuals seem to be drawn to self-employment (Dawson, de Meza, Henley, \& Arabsheibani, 2014). And although some studies report negative associations between (over)optimism and entrepreneurial 
outcomes, in general optimism has positive effects on self-employed individuals' judgments and decision-making about their firms (e.g., Koudstaal et al., 2015). Indeed, a study about the moderating role of PsyCap on the relationship between start-up capital and entrepreneurial success in Uganda, has shown that optimism had the strongest influence (Baluku et al., 2016), and that PsyCap predicted business success over and above the presence of start-up grants.

Some researchers (e.g., Andersson, 2012; Chen, Zhou, Yang, Bao, \& Wang, 2017) suggest that the mechanism underlying the positive influence of optimism on entrepreneurial success could be social support or social network size: optimistic individuals tend to form more varied and larger social networks than pessimistic individuals, and more often communicate and cooperate with them. In addition to business success, social support has been found to be related to entrepreneurial intentions more indirectly, by increasing individuals' entrepreneurial self-efficacy and outcome expectancies (Lent, 2005). Bandura (1986) already showed that social support, expressed in the form of positive feedback, approval, and encouragement positively affects self-efficacy beliefs. Indeed, there is a significant body of evidence that self-efficacy and positive outcome expectancies (or optimism) increase individuals' entrepreneurial intentions (e.g., Atitsogbe, Mama, Sovet, Pari, \& Rossier, 2019; Lent, Paixão, Silva, \& Leitão, 2010; Zhao, Seibert, \& Hills, 2005).

Self-efficacy is defined an individuals' belief to be capable of performing a certain task successfully - or more generally, confidence in one's abilities. Efficacy beliefs develop over time and can be influenced by an individuals' psychological state as well as various learning experiences (Bandura, 1986). Importantly, Zhao et al. (2005) showed that among others, entrepreneurial experience and learning influenced entrepreneurial self-efficacy, which in turn predicted entrepreneurial intentions. They furthermore suggest that especially in the pre-launch stage of the entrepreneurial process, it may be worthwhile to focus on increasing individuals' confidence in the ability to run their own business (i.e., increase their entrepreneurial self-efficacy), and that EET programs should incorporate components to influence the antecedents of self-efficacy: mastery experiences, role modeling, and social persuasion (Zhao et al., 2005).

The positive role of hope in work, which is defined as a "[...] positive motivational state that is based on an interactively derived sense of successful (1) agency (goal-directed energy) and (2) pathways (planning to meet goals)" (Snyder, Irving, \& Anderson, 1991, p. 287). Hope thus translates to willpower as well as an ability to devise alternative paths to achieve a goal in the face of obstacles or setbacks, and to view these obstacles in terms of challenges and learning opportunities. Hope prevents an individual from becoming overwhelmed by work-related stressors. Research has established that individuals with higher levels of hope have higher intentions to start their own business (Jensen \& Luthans, 2006). The positive association between positive affect and goal commitment has shown to be mediated by hope (Uy, Foo, \& Baron, 2009), which thereby increases the probability of achieving one's entrepreneurial goals (Laguna, 2008).

Similar to hope, resilience is characterized by persistence toward goal attainment, even in de face of adversity or when confronted with obstacles. It has 
been defined as "an ability to go on with life, or to continue living a purposeful life, after hardship or adversity" (Tedeschi \& Calhoun, 2004, p. 4), as well as "a dynamic process encompassing positive adaptation within the context of significant adversity" (Luthar, Cicchetti, \& Becker, 2000, p. 543). In the context of self-employment, resilience develops from experiencing unforeseen or remarkable situations, and learning to "roll with the punches." It is thus particularly essential for entrepreneurs, who often start their business faced with uncertainties, and have to manage stress on a daily basis. Research by Fisher, Maritz, and Lobo (2016) shows that entrepreneurs are indeed more resilient than other populations, and that it consists of hardiness, resourcefulness, and is predictive of entrepreneurial success. Resilience is furthermore associated with optimism (ManzanoGarcía \& Calvo, 2013) and self-efficacy (Bullough \& Renko, 2013).

\section{Psychological Capital and (Employee) Well-being}

Hope, efficacy, resilience, and optimism thus each are uniquely related to either entrepreneurial intentions or success. Moreover, these positive psychological resources also have shown to mediate the relationships between more distal factors (e.g., positive affect, learning experiences resulting from support, or courage) and entrepreneurial intentions or success (Bockorny \& Youssef-Morgan, 2019; Zhao et al., 2005). Although these separate constructs thus each have unique contributions to outcome measures, they also share a common core, which is characterized by a focus on identifying one's strengths, making positive appraisals of one's chances of success, and having a perception that one's goals are within reach and under one's control. This second-order construct is called PsyCap. In addition to human capital ("what you know") and social capital ("who you know"), PsyCap is concerned with "who you are" and "who you are becoming" (cf. Newman, Ucbasaran, Zhu, \& Hirst, 2014). Specifically, as defined by Luthans, Youssef et al. (2007), an individual who scores high on PsyCap is

\section{[...] characterized by: (1) having confidence (efficacy) to take on and put in the necessary effort to succeed at challenging tasks; (2) making a positive attribution (optimism) about succeeding now and in the future; (3) persevering toward goals, and when necessary, redirecting paths to goals (hope) in order to succeed; and (4) when beset by problems and adversity, sustaining and bouncing back and even beyond (resilience) to attain success. (Luthans et al., 2007, p. 3)}

Importantly, PsyCap has also been shown to be directly and indirectly related to (occupational) well-being and health. High levels of PsyCap allow employees to appraise situations and circumstances in more positive, adaptive and promotionoriented ways, enhancing their well-being. For example, Avey, Luthans, Smith, and Palmer (2010) showed that PsyCap was positively associated with employee well-being over time, and Luthans, Youssef, Sweetman, and Harms (2013) also established a link between PsyCap and overall well-being and life satisfaction, stating " [...] PsyCap appears to be a particularly relevant operationalization of positivity in relation to well-being in general, and human resource management and development in the workplace in particular" (p. 128). Additionally, Culbertson, Fullagar, and Mills (2010) showed that the positive effect of PsyCap on well-being extends beyond job satisfaction to overall satisfaction with life. 
In their research, they showed that PsyCap was related to positive functioning, and to both hedonic and eudaimonic well-being across two weeks and on a daily basis. There are also indications that PsyCap indirectly influences occupational or vocational well-being, for example, via change-oriented coping mechanisms (Rabenu, Yaniv, \& Elizur, 2017), meaning in life (Li, 2018), or emotional labor (Zhao \& You, 2019).

\section{Psychological Capital and Self-employment}

The underlying cognitive component shared by all four constructs within the PsyCap concept (i.e., hope, efficacy, resilience, and optimism), represents one's "[...] positive appraisal of circumstances and probability for success based on motivated effort and perseverance" (Luthans, Avolio et al., 2007; p. 550). Thereofore, PsyCap is, in our opinion, directly related to the task of entrepreneurship, and research indeed shows positive effects of higher levels of PsyCap among entrepreneurs.

For example, Hmieleski and Carr (2008) showed that PsyCap explained performance of new ventures better than financial capital, social capital, or human capital. Furthermore, in a study by Contreras, De Dreu, and Espinosa (2017), entrepreneurial intention was related to the higher-order construct of PsyCap as well as the separate dimensions of PsyCap, in particular self-efficacy and resilience. A recent study by Bockorny and Youssef-Morgan (2019) that higher levels of PsyCap increased the life satisfaction of entrepreneurs, and mediated the effect of courage on entrepreneurial life satisfaction. There are also indications that higher levels of PsyCap are related to innovative performance (Abbas \& Raja, 2015), such that high PsyCap individuals were more likely to generate and implement novel ideas in their workplace. Arguably, even though these findings were reported for employees, the ability of innovativeness is essential for entrepreneurs. Further, stress levels among entrepreneurs are often affected by their PsyCap: It is often assumed that entrepreneurs are exposed to, and experience, high levels of stress, caused by influences such as rapid changes, unpredictable environments, work overload, and the personal responsibility for others. However, successful entrepreneurs may be relatively high in the capacity to tolerate or effectively manage stress, and subjectively experience low levels of stress, which may be explained by their higher levels of PsyCap (e.g., Baron, Franklin, \& Hmieleski, 2016). Moreover, research by Hmieleski, Carr, and Baron (2015) indicates that PsyCap enhances entrepreneurial performances in dynamic environments, that is, contexts characterized by uncertainty (e.g., whether one's ideas can be converted into tangible services or products).

To summarize, the research reviewed here suggests that entrepreneurial performance is increased if individuals have high levels of PsyCap. Importantly, PsyCap is a highly malleable construct which can be developed or trained (Luthans et al., 2007). This suggests that incorporating PsyCap training into EET may enhance the positive effects of EET for (long-term) unemployed individuals reported elsewhere. In the last section of this chapter, we will therefore provide some suggestions on how such a PsyCap training component could be incorporated in EET, 
as well as a brief discussion of some boundary conditions to self-employment and entrepreneurial performance and survival.

\title{
PICKING UP THE REIGNS: INCORPORATING PSYCAP IN ENTREPRENEURSHIP EDUCATION AND TRAINING
}

\author{
Self-employment for the Unemployed: Drawbacks and Boundaries
}

The support offered to individuals who aspire to become self-employed ranges from coaching and counselling, to direct financial support in the form of subsidized loans or grants, and various combinations of these types of support (see e.g., Valerio et al., 2014). As Caliendo (2016) argues, self-employment may be especially viable as a solution to long-term unemployment for individuals whose work is undervalued in paid employment (e.g., due to low educational attainment) or for those whose options are limited because of labor market constraints or structural changes in certain industries (e.g., increased robotization in certain industries). These policies and programs have been shown to be effective and meaningful for unemployed participants, as they provide these individuals with employment and allow them to become independent of welfare benefits (see e.g., Caliendo, 2016). However, authors have also noted that these programs, and in particular the provision of start-up grants or subsidies for unemployed individuals, may have some drawbacks or risks, some of which we will summarize below.

There are indications that self-employment out of unemployment, compared to self-employment out of employment, is more often driven by necessity - since alternative employment options are often lacking. The long-term unemployed often deal with a range of other issues such as financial difficulties, and health and housing problems. Businesses created in such contexts, by individuals with less access to information about the requirements and opportunities of entrepreneurship, as well as a lack of skills relevant to running a business are more likely to fail, or only generate minimal incomes (e.g., Caliendo, 2016). Indeed, especially for long-term unemployed individuals, there is an increased likelihood of a loss in previously acquired human and social capital, as well as a reduction (or elimination) of business and social networks, which may make these individuals less competent to run a new firm (e.g., Van Stel \& Storey, 2004). For unemployed youth, these concerns are likely even larger, given their lack of work experiences.

Furthermore, entrepreneurial motivation seems to be weakened if there is a mismatch in person-environment fit (Zhou, Zhou, Zhang, Obschonka, \& Silbereisen, 2019). A good person-environment fit between an individuals' personality and the personality composition of a region in which a person lives that is, the so-called "entrepreneurial ecosystem" - has shown to significantly predict higher individual positive psychological outcomes, such as a higher self-esteem and psychological well-being (Jokela, Bleidorn, Lamb, Gosling, \& Rentfrow, 2015). Lower levels of these psychological characteristics are detrimental for both entrepreneurial intentions as well as success. For example, Wagner (2002) showed that a favorable entrepreneurial ecosystem, indicated by higher levels of start-up activity, as well as increased numbers of unemployed 
individuals creating start-ups, positively affects individuals' intention to become self-employed. Additionally, this research revealed that a lack of contact with other entrepreneurs - that is lack of role models - negatively affect intentions to become self-employed (Wagner, 2002). Relevant to person-environment fit are also the demographic characteristics of the EET target population in the sense that different target groups require different policies and programs. For example, unemployed women may have different needs and skills than unemployed migrants or unemployed youth, and vice versa.

Lastly, there are indications that unemployment causes a shift in individuals' time perspective; specifically, there tends to be a shift from future-oriented thinking to more present-fatalistic and short-term oriented thinking styles. One's time perspective describes how one's subconscious perception or weighing of the past, present, and future influences decision-making (Zimbardo \& Boyd, 1999), and has consequences for our physical and mental health (e.g., Stolarski, Matthews, Postek, Zimbardo, \& Bitner, 2014). A present-fatalistic thinking style is characterized by "a fatalistic, helpless, and hopeless attitude toward the future and life" (Zimbardo \& Boyd, 1999, p. 1275), and is generally associated with lower levels of well-being and life satisfaction (Stolarski et al., 2014), and with strong feelings of a lack of control over life (Zimbardo \& Boyd, 1999). A future time perspective on the other hand often causes the individual to regulate their behavior, establish goals and expectations, and to motivate and monitor performance. Indeed, research has shown that entrepreneurs tend to have future-oriented time perspectives, which was related to an increased likelihood of entrepreneurial success (Przepiorka, 2016).

\section{Future-oriented Thinking Styles and Enhancing Strengths: A Focus on PsyCap in EET}

Although there are thus some disadvantages to stimulating the long-term unemployed to become self-employed, we feel that many of these inherent risks could be reduced if EET programs would also incorporate a PsyCap component. Including PsyCap will both enhance the existing psychological strengths of unemployed individuals - that is those characteristics and skills relevant for entrepreneurship - as well as shift their thinking style from present-fatalistic to more future-oriented. Indeed, recent research shows that individuals who received PsyCap training increased their job search behavior and were more likely to find employment at a three months follow-up (Georgiou, Nikolaou, \& Turban, 2019).

Especially at the beginning of the entrepreneurial process, a future orientation is a prerequisite for making decisions, implementing one's ideas and working toward goal attainment. Future-oriented individuals are more likely to focus on planning and achieving future goals, as well as considering - and taking responsibility for - future consequences of present actions (e.g., Zimbardo \& Boyd, 1999). However, there are indications that unemployed individuals tend to hold perceptions that the future cannot be influenced by individual actions, and that one is at the mercy of "fate." We want to propose that by increasing levels of PsyCap among unemployed aspiring entrepreneurs, one could create a more 
future-oriented thinking style. The common core of the different elements which together form PsyCap is a "[...] cognitive agentic component that motivates effort, perseverance, and a positive outlook throughout the process of pursuing challenging goals one chooses to believe are possible" (Luthans et al., 2013). This definition indicates that future-oriented thinking is inherent to the construct of PsyCap, as well as to its four components hope, optimism, efficacy, and resilience. Research has shown that even after failure, high levels of PsyCap allow individuals to pick up the reigns (again): Rhoads (2016) shows that high levels of PsyCap increased the likelihood of future entrepreneurial activity after the failure of a business venture among entrepreneurs.

PsyCap can be increased by brief (two to three hours), one-session, interactive micro-interventions, which make them suitable to be implemented in regular EE and ET activities. Research using randomized controlled designs showed significant increases in PsyCap in the experimental group, both directly after the intervention as well as after one month (Dello Russo \& Stoykova, 2015) and eight weeks (Luthans, Luthans, \& Avey, 2014). Typically, a PsyCap Intervention (PCI; outlined by Luthans, Avey, Avolio, Norman, \& Combs, 2006) is conducted in small groups, and consists of individual exercises with the focus on incorporating self-reflection and goal-setting, as well as group discussions. Self-reflection exercises will help participants to reflect on what might stop them from accomplishing their goals, which encourages the individual to anticipate, plan for, and overcome potential obstacles. Group discussions are incorporated into the intervention to encourage positive thinking and vicarious learning through peer role modeling, and to optimize participants' psychological resources in the form of social support. We feel that the presence of other individuals with similar goals - fellow would-be entrepreneurs - is thus crucial to the success of PCIs: Discussing goals and how to attain them, receiving and providing constructive and positive feedback, and gaining a more "objective" perspective on one's (business) plans can increase intrinsic motivation and in turn reinforces one's resolutions. It is important that the sessions are supervised by facilitators familiar with PsyCap, since they can encourage positive self-talk among participants, and maintains the focus on goal-setting, identification of pathways toward one's goals, and overcoming obstacles (e.g., Luthans et al., 2006, 2007).

We recommend that participants in EET programs acquire, where possible, "real" skills - for example, in the form of internships and Q\&A sessions with both new and experienced entrepreneurs. This allows them to practice what they have learnt, allow them to focus on and gain mastery experiences, and will further strengthen their self-efficacy. And, although role playing is not always appreciated by participants in workshops or training sessions, this technique can increase self-efficacy if it is accompanied by constructive feedback from a facilitator (see e.g., Kok, 2014).

\section{CONCLUSION}

The aim of the current chapter was to provide an overview of the literature on self-employment as a possible solution out of unemployment, and to review 
which psychological traits and characteristics promote successful entrepreneurship and (occupational) well-being. In particular, we have highlighted how the individual components of PsyCap - hope, optimism, efficacy, and resilience as well as the second-order construct of PsyCap increase entrepreneurial intentions and success and have a positive influence on well-being. Given the fact that PsyCap can be increased in a relatively short-time span, we argue that in addition to acquiring the necessary knowledge and skills during EET, incorporating a PsyCap component may result in more sustainable positive outcomes and may further empower unemployed would-be entrepreneurs participating in such programs. PCIs are inherently strength-based, and incorporating this element in traditional EET is likely to not only increase entrepreneurial intentions and success, but also increases participants' well-being, self-esteem, and the general confidence they can pick up the reigns and take back control over their (professional) lives.

\section{REFERENCES}

Abbas, M., \& Raja, U. (2015). Impact of psychological capital on innovative performance and job stress. Canadian Journal of Administrative Sciences, 32(2), 128-138.

Andersson, M. A. (2012). Dispositional optimism and the emergence of social network diversity. Sociological Quarterly, 53, 92-115.

Atitsogbe, K. A., Mama, N. P., Sovet, L., Pari, P., \& Rossier, J. (2019). Perceived employability and entrepreneurial intentions across university students and job seekers in Togo: The effect of career adaptability and self-efficacy. Frontiers in Psychology, 10, 180. doi:10.3389/fpsyg.2019.00180

Avey, J. B., Luthans, F., Smith, R. M., \& Palmer, N. F. (2010). Impact of positive psychological capital on employee well-being over time. Journal of Occupational Health Psychology, 15, $17-28$.

Awogbenle, A. C., \& Iwuamadi, K. C. (2010). Youth unemployment: Entrepreneurship development programme as an intervention mechanism. African Journal of Business Management, 4(6), $831-835$.

Baluku, M. M., Kikooma, J. F., \& Kibanja, G. M. (2016). Psychological capital and the startup capital-entrepreneurial success relationship. Journal of Small Business \& Entrepreneurship, 28(1), 27-54. doi:10.1080/08276331.2015.1132512

Bandura, A. (1986). Social foundations of thought and action: A social cognitive theory. Englewood Cliffs, NJ: Prentice-Hall.

Baron, D. P. (2007). Corporate social responsibility and social entrepreneurship. Journal of Economics \& Management Strategy, 16(3), 683-717. doi:10.1111/j.1530-9134.2007.00154.x

Baron, R. A., Franklin, R. J., \& Hmieleski, K. M. (2016). Why entrepreneurs often experience low, not high, levels of stress: The joint effects of selection and psychological capital. Journal of Management, 42(3), 742-768.

Benz, M. (2009). Entrepreneurship as a non-profit-seeking activity. International Entrepreneurship and Management Journal, 5(1), 23-44.

Blanchflower, D. G., \& Meyer, B. D. (1994). A longitudinal analysis of the young self-employed in Australia and the United States. Small Business Economics, 6(1), 1-19.

Blattman, C., Fiala, N., \& Martinez, S. (2014). Generating skilled self-employment in developing countries: Experimental evidence from Uganda. The Quarterly Journal of Economics, 129(2), $697-752$.

Bockorny, K., \& Youssef-Morgan, C. M. (2019). Entrepreneurs' courage, psychological capital, and life satisfaction. Frontiers in Psychology, 10, 789. doi:10.3389/fpsyg.2019.00789

Bullough, A., \& Renko, M. (2013). Entrepreneurial resilience during challenging times. Business Horizons, 56(3), 343-350.

Bureau of Labor Statistics. (2016). Entrepreneurship and the U.S. economy. Retrieved from https:// www.bls.gov/bdm/entrepreneurship/entrepreneurship.htm. Accessed on July 14, 2019. 
Caliendo, M. (2016), Start-up subsidies for the unemployed: Opportunities and limitations. Bonn: IZA World of Labor. doi:10.15185/izawol.200

Caliendo, M., Fossen, F. M., \& Kritikos, A. S. (2009). Risk attitudes of nascent entrepreneurs: New evidence from an experimentally validated survey. Small Business Economics, 32(2), 153-167.

Caliendo, M., \& Künn, S. (2011). Start-up subsidies for the unemployed: Long-term evidence and effect heterogeneity. Journal of Public Economics, 95(3-4), 311-331.

Chandler, G. N., \& Hanks, S. H. (1994). Founder competence, the environment, and venture performance. Entrepreneurship, Theory and Practice, 18(3), 77-89.

Chen, Y., Zhou, X., Yang, G., Bao, J., \& Wang, G. (2017). Social networks as mediator in entrepreneurial optimism and new venture performance. Social Behavior and Personality: An International Journal, 45(4), 551-562.

Christiansen, C., Backman, C., Little, B., \& Nguyen, A. (1999). Occupations and wellbeing: A study of personal projects. American Journal of Occupational Therapy, 53(1), 91-99.

Contreras, F., De Dreu, I., \& Espinosa, J. (2017). Examining the relationship between psychological capital and entrepreneurial intention: An exploratory study. Asian Social Science, 13, 80. doi:10.5539/ass.v13n3p80

Cooper, A. C., Woo, C. Y., \& Dunkelberg, W. C. (1988). Entrepreneurs' perceived chances for success. Journal of Business Venturing, 3, 97-108. doi:10.1016/0883-9026(88)90020-1

Crant, J. M. (1996). The proactive personality scale as a predictor of entrepreneurial intentions. Journal of Small Business Management, 34(3), 42-49.

Croson, D. C., \& Minniti, M. (2012). Slipping the surly bonds: The value of autonomy in self-employment. Journal of Economic Psychology, 33(2), 355-365.

Culbertson, S. S., Fullagar, C. J., \& Mills, M. J. (2010). Feeling good and doing great: The relationship between psychological capital and well-being. Journal of Occupational Health Psychology, 15, 421-433.

Dawson, C., de Meza, D., Henley, A., \& Arabsheibani, G. R. (2014). Entrepreneurship: Cause and consequence of financial optimism. Journal of Economics \& Management Strategy, 23(4), $717-742$.

Dello Russo, S., \& Stoykova, P. (2015). Psychological capital intervention (PCI): A replication and extension. Human Resource Development Quarterly, 26, 329-347

Dvouletý, O. (2018). Determinants of self-employment with and without employees: Empirical findings from Europe. International Review of Entrepreneurship, 16, 405-426.

Dvouletý, O., \& Lukeš, M. (2016). Review of empirical studies on self-employment out of unemployment: Do self-employment policies make a positive impact? International Review of Entrepreneurship, 14(3), 361-376.

Elert, N., Andersson, F. W., \& Wennberg, K. (2015). The impact of entrepreneurship education in high school on long-term entrepreneurial performance. Journal of Economic Behavior \& Organization, 111, 209-223.

Fairlie, R. W., \& Holleran, W. (2012). Entrepreneurship training, risk aversion and other personality traits: Evidence from a random experiment. Journal of Economic Psychology, 33(2), 366-378.

Feldman, D. C. (1996). The nature, antecedents and consequences of underemployment. Journal of Management, 22(3), 385-407. doi:10.1016/S0149-2063(96)90030-6

Feldman, D. C., Leana, C. R., \& Bolino, M. C. (2002). Underemployment and relative deprivation among re-employed executives. Journal of Occupational and Organizational Psychology, 75(4), 453-471. doi:10.1348/096317902321119682

Fisher, R., Maritz, A., \& Lobo, A. (2016). Does individual resilience influence entrepreneurial success? Academy of Entrepreneurship Journal, 22(2), 39-53.

Fraser, S., \& Greene, F. J. (2006). The effects of experience on entrepreneurial optimism and uncertainty. Economica, 73(290), 169-192.

Gartner, W. B. (1988). "Who is an entrepreneur?" is the wrong question. American journal of Small Business, 12(4), 11-32.

Georgiou, K., Nikolaou, I., \& Turban, D. B. (2019). The impact of a training intervention developing Psychological Capital on job search success. Journal of Career Development. doi: $10.1177 / 0894845319852425$

Gorgievski, M. J., Ascalon, M. E., \& Stephan, U. (2011). Small business owners' success criteria, a values approach to personal differences. Journal of Small Business Management, 49(2), 207-232. 
Greenberger, E., \& O’Neil, R. (1993). Spouse, parent, worker: Role commitments and role-related experiences in the construction of adults' well-being. Developmental Psychology, 29(2), 181-197.

Hammarström, A., \& Janlert, U. (2002). Early unemployment can contribute to adult health problems: Results from a longitudinal study of school leavers. Journal of Epidemiology and Community Health, 56(8), 624-630. doi:10.1136/jech.56.8.624

Hessels, J., Rietveld, C. A., \& van der Zwan, P. (2017). Self-employment and work-related stress: The mediating role of job control and job demand. Journal of Business Venturing, 32, 178-196.

Hessels, J., Van Gelderen, M., \& Thurik, R. (2008). Entrepreneurial aspirations, motivations, and their drivers. Small Business Economics, 31(3), 323-339.

Hmieleski, K. M., \& Carr, J. C. (2008). The relationship between entrepreneur psychological capital and new venture performance. Paper presented at the Babson College, Babson College Entrepreneurship Research Conference (BCERC).

Hmieleski, K. M., Carr, J. C., \& Baron, R. A. (2015). Integrating discovery and creation perspectives of entrepreneurial action: The relative roles of founding CEO human capital, social capital, and psychological capital in contexts of risk versus uncertainty. Strategic Entrepreneurship Journal, 9(4), 289-312.

International Labour Office. (2015). Key indicators of the labour market. Geneva: International Labour Office.

International Labour Office. (2018). Decent work and the sustainable development goals: A guidebook on SDG labour market indicators. Geneva: International Labour Organization.

Jahoda, M. (1982). Employment and unemployment. Cambridge: Cambridge University Press.

Jensen, S. M., \& Luthans, F. (2006). Relationship between entrepreneurs' psychological capital and their authentic leadership. Journal of Managerial Issues, 28, 254-273.

Jokela, M., Bleidorn, W., Lamb, M. E., Gosling, S. D., \& Rentfrow, P. J. (2015). Geographically varying associations between personality and life satisfaction in the London metropolitan area. Proceedings of the national academy of sciences of the United States of America, 112(3), 725-730. doi:10.1073/pnas.1415800112

Kanfer, R., Wanberg, C. R., \& Kantrowitz, T. M. (2001). Job search and employment: A personalitymotivational analysis and meta-analytic review. Journal of Applied Psychology, 86(5), 837-855. doi:10.1037/0021-9010.86.5.837

Karasek, R. A., \& Theorell, T. (1990). Healthy work: Stress, productivity and the reconstruction of working life. New York, NY: Basic Books.

Klein, H. J., Wesson, M. J., Hollenbeck, J. R., \& Alge, B. J. (1999). Goal commitment and the goal-setting process: Conceptual clarification and empirical synthesis. Journal of Applied Psychology, 84(6), 885-896.

Kok, G. (2014). A practical guide to effective behavior change: How to apply theory- and evidencebased behavior change methods in an intervention. European Health Psychologist, 16(5), 156-170.

Korunka, C., Kessler, A., Frank, H., \& Lueger, M. (2010). Personal characteristics, resources, and environment as predictors of business survival. Journal of Occupational and Organizational Psychology, 83(4), 1025-1051.

Koudstaal, M., Sloof, R., \& Van Praag, M. (2015). Are entrepreneurs more optimistic and overconfident than managers and employees? Discussion Paper No. 15-124/VII. Tinbergen Institute, Amsterdam.

Kuchinke, K. P., Ardichvili, A., Borchert, M., \& Rozanski, A. (2009). The meaning of working among professional employees in Germany, Poland and Russia. Journal of European Industrial Training, 33(2), 104-124.

Kuhl, J. (1994). A theory of action and state orientations. In J. Kuhl \& J. Beckmann (Eds.), Volition and personality: Action versus state orientation (pp. 9-46). Seattle, WA: Hogrefe \& Huber.

Laguna, M. (2008). Positive psychological capital and process of business start-up. International Journal of Psychology, 43(3-4), 390-391.

Law, M., Steinwender, S., \& Leclair, L. (1998). Occupation, health and well-being. Canadian Journal of Occupational Therapy, 65(2), 81-91.

Lazear, E. P. (2004). Balanced skills and entrepreneurship. American Economic Review, 94(2), $208-211$.

Lent, R. W. (2005). A social cognitive view of career development and counseling. In S. D. Brown \& R. W. Lent (Eds.), Career development and counseling: Putting theory and research to work (pp. 101-127). Hoboken, NJ: JohnWiley. 
Lent, R. W., Paixão, M. P., Silva, J. T. D., \& Leitão, L. M. (2010). Predicting occupational interests and choice aspirations in Portuguese high school students: A test of social cognitive career theory. Journal of Vocational Behavior, 76, 244-251. doi:10.1016/j.jvb.2009.10.001

Li, Y. (2018). Building well-being among university teachers: The roles of psychological capital and meaning in life. European Journal of Work and Organizational Psychology, 27, 594-602.

Lodi-Smith, J., \& Roberts, B. W. (2007). Social investment and personality: A meta-analysis of the relationship of personality traits to investment in work, family, religion, and volunteerism. Personality and Social Psychology Review, 11(1), 68-86.

Lucas, R. E., Clark, A. E., Georgellis, Y., \& Diener, E. (2004). Unemployment alters the set point for life satisfaction. Psychological Science, 15(1), 8-13. doi:10.1111/j.0963-7214.2004.01501002.x

Luthans, B. C., Luthans, K. W., \& Avey, J. B. (2014). Building the leaders of tomorrow: The development of academic psychological capital. Journal of Leadership \& Organizational Studies, 21(2), 191-199.

Luthans, F., Avey, J. B., Avolio, B. J., Norman, S. M., \& Combs, G. M. (2006). Psychological capital development: Toward a micro-intervention. Journal of Organizational Behavior, 27, 387-393.

Luthans, F., Avolio, B. J., Avey, J. B., \& Norman, S. M. (2007). Positive psychological capital: Measurement and relationship with performance and satisfaction. Personnel Psychology, 60(3), $541-572$.

Luthans, F., Youssef, C. M., \& Avolio, B. J. (2007). Psychological capital: Developing the human competitive edge. Oxford: Oxford University Press.

Luthans, F., Youssef, C. M., Sweetman, D. S., \& Harms, P. D. (2013). Meeting the leadership challenge of employee well-being through relationship PsyCap and health PsyCap. Journal of Leadership \& Organizational Studies, 20, 118-133.

Luthar, S. S., Cicchetti, D., \& Becker, B. (2000). The construct of resilience: A critical evaluation and guidelines for future work. Child Development, 71, 543-562.

Manzano-García, G., \& Calvo, J. C. A. (2013). Psychometric properties of Connor-Davidson Resilience Scale in a Spanish sample of entrepreneurs. Psicothema, 25(2), 245-251.

McKee-Ryan, F. M., Song, Z., Wanberg, C. R., \& Kinicki, A. J. (2005). Psychological and physical well-being during unemployment: A meta-analytic study. Journal of Applied Psychology, 90(1), 53-76. doi:10.1037/0021-9010.90.1.53

Michaelides, M., \& Benus, J. (2012). Are self-employment training programs effective? Evidence from Project GATE. Labour Economics, 19(5), 695-705. doi:10.1016/j.labeco.2012.04.004

Millán, J. M., Congregado, E., \& Román, C. (2012). Determinants of self-employment survival in Europe. Small Business Economics, 38(2), 231-258.

Ming, Z., \& Zuguang, H. (2013, November). The entrepreneurial psychological capital and the study of entrepreneurship. In 2013 6th International conference on information management, innovation management and industrial engineering (Vol. 2, pp. 135-137). Shaanxi, China.

Minola, T., Criaco, G., \& Obschonka, M. (2016). Age, culture, and self-employment motivation. Small Business Economics, 46(2), 187-213.

Moore, T. H. M., Kapur, N., Hawton, K., Richards, A., Metcalfe, C., \& Gunnell, D. (2017). Interventions to reduce the impact of unemployment and economic hardship on mental health in the general population: A systematic review. Psychological Medicine, 47(6), 1062-1084. doi:10.1017/ S0033291716002944

Newman, A., Ucbasaran, D., Zhu, F. E. I., \& Hirst, G. (2014). Psychological capital: A review and synthesis. Journal of Organizational Behavior, 35(S1), S120-S138.

Luthans, F., Avey, J. B., \& Patera, J. L. (2008). Experimental analysis of a web-based training intervention to develop positive psychological capital. Academy of Management Learning \& Education, $7(2), 209-221$.

OECD. (2019, July 10), Youth unemployment rate (indicator). OECD. doi:10.1787/c3634df7-en

Owens, K. S., Kirwan, J. R., Lounsbury, J. W., Levy, J. J., \& Gibson, L. W. (2013). Personality correlates of self-employed small business owners' success. Work, 45, 73-85. doi:10.3233/WOR-121536

Paul, K. I., \& Batinic, B. (2010). The need for work: Jahoda's latent functions of employment in a representative sample of the German population. Journal of Organizational Behavior, 31(1), 45-64. doi:10.1002/job.622 
Paul, K. I., \& Moser, K. (2009). Unemployment impairs mental health: Meta-analyses. Journal of Vocational Behavior, 74(3), 264-282. doi:10.1016/j.jvb.2009.01.001

Peterson, C., \& Seligman, M. E. P. (2004). Character strengths and virtues: A handbook and classification. New York, NY: Oxford University Press.

Przepiorka, A. (2016). What makes successful entrepreneurs different in temporal and goal-commitment dimensions? Time \& Society, 25(1), 40-60.

Przepiorka, A. M. (2017). Psychological determinants of entrepreneurial success and life-satisfaction. Current Psychology, 36(2), 304-315. doi:10.1007/s12144-016-9419-1

Rabenu, E., Yaniv, E., \& Elizur, D. (2017). The relationship between psychological capital, coping with stress, well-being, and performance. Current Psychology, 36, 875-887.

Rauch, A., \& Frese, M. (2007). Let's put the person back into entrepreneurship research: A metaanalysis on the relationship between business owners' personality traits, business creation, and success. European Journal of Work and Organizational Psychology, 16(4), 353-385.

Razmus, W., \& Laguna, M. (2018). Dimensions of entrepreneurial success: A multilevel study on stakeholders of micro-enterprises. Frontiers in Psychology, 9(791). doi:10.3389/fpsyg.2018.00791

Rhoads, K. (2016). Stepping stones or stumbling blocks: Psychological capital and overcoming new venture failure. Journal of Management, 4(2), 11-21.

Ryan, R. M., \& Deci, E. L. (2000). Self-determination theory and the facilitation of intrinsic motivation, social development, and well-being. American Psychologist, 55(1), 68-78. doi:10.1037/0003066X.55.1.68

Sage, D. (2019). Unemployment, wellbeing and the power of the work ethic: Implications for social policy. Critical Social Policy, 39(2), 205-228. doi:10.1177/0261018318780910

Scheier, M. F., Carver, C. S., \& Bridges, M. W. (2001). Optimism, pessimism, and psychological wellbeing. In E. C. Chang (Ed.), Optimism and pessimism: Implications for theory, research, and practice (pp. 189-216). Washington, DC: American Psychological Associat

Selenko, E., Batinic, B., \& Paul, K. (2011). Does latent deprivation lead to psychological distress? Investigating Jahoda's model in a four-wave study. Journal of Occupational and Organizational Psychology, 84(4), 723-740. doi:10.1348/096317910x519360

Shane, S. (2009). Why encouraging more people to become entrepreneurs is bad public policy. Small Business Economics, 33(2), 141-149.

Snyder, C. R., Irving, L. M., \& Anderson, J. R. (1991). Hope and health. Handbook of Social and Clinical Psychology: The Health Perspective, 162, 285-305.

Stolarski, M., Matthews, G., Postek, S., Zimbardo, P. G., \& Bitner, J. (2014). How we feel is a matter of time: Relationships between time perspectives and mood. Journal of Happiness Studies, 15, 809-827.

Strandh, M., Winefield, A., Nilsson, K., \& Hammarström, A. (2014). Unemployment and mental health scarring during the life course. European Journal of Public Health, 24(3), 440-445. doi:10.1093/eurpub/cku005

Sustainable Development Knowledge Platform. (2019). Progress Report Goal 8: Promote sustained, inclusive and sustainable economic growth, full and productive employment and decent work for all. Retrieved from https://sustainabledevelopment.un.org/sdg8. Accessed on July 9, 2019.

Sutanto, E. M., \& Eliyana, A. (2014). The study of entrepreneurial characteristics with achievement motivation and attitude as the antecedent variables. Researchers World, 5(4), 125.

Tedeschi, R. G., \& Calhoun, L. G. (2004). Posttraumatic growth: Conceptual foundations and empirical evidence. Psychological Inquiry, 15, 1-18.

Thurik, A. R., Carree, M. A., Van Stel, A., \& Audretsch, D. B. (2008). Does self-employment reduce unemployment? Journal of Business Venturing, 23(6), 673-686.

Uy, M., Foo, M. D., \& Baron, R. A. (2009). How do feelings influence effort? An empirical study of entrepreneurs' affect and venture effort. Journal of Applied Psychology, 94(4), 1086-1094.

Valerio, A., Parton, B., \& Robb, A. (2014). Entrepreneurship education and training programs around the world: Dimensions for success. Washington, DC: The World Bank.

Van Stel, A., \& Storey, D. (2004). The link between firm births and job creation: Is there a Upas tree effect? Regional Studies, 38(8), 893-909.

Vinokur, A. D., Price, R. H., \& Schul, Y. (1995). Impact of the JOBS intervention on unemployed workers varying in risk for depression. American Journal of Community Psychology, 23(1), 39-74. doi:10.1007/bf02506922 
Vinokur, A. D., \& Schul, Y. (1997). Mastery and inoculation against setbacks as active ingredients in the JOBS intervention for the unemployed. Journal of Consulting and Clinical Psychology, 65(5), 867-877. doi:10.1037/0022-006X.65.5.867

Vinokur, A. D., van Ryn, M., Gramlich, E. M., \& Price, R. H. (1991). Long-term follow-up and benefitcost analysis of the jobs program: A preventive intervention for the unemployed. Journal of Applied Psychology, 76(2), 213. doi:10.1037/0021-9010.76.2.213

Vuori, J., \& Vesalainen, J. (1999). Labour market interventions as predictors of re-employment, job seeking activity and psychological distress among the unemployed. Journal of Occupational and Organizational Psychology, 72(4), 523-538. doi:10.1348/096317999166824

Wagner, J. (2002). The impact of risk aversion, role models, and the regional milieu on the transition from unemployment to self-employment: Empirical evidence for Germany. Discussion Paper No. 468. University of Lueneburg, Lueneburg.

Wall, T. D., Jackson, P. R., Mullarkey, S., \& Parker, S. K. (1996). The demand-control model of job strain: A more specific test. Journal of Occupational and Organizational Psychology, 69, 153-66.

Whelan, N., McGilloway, S., Murphy, M. P., \& McGuinness, C. (2018). EEPIC - Enhancing employability through positive interventions for improving career potential: The impact of a high support career guidance intervention on the wellbeing, hopefulness, self-efficacy and employability of the long-term unemployed - A study protocol for a randomised controlled trial. Trials, 19(1), 141-141. doi:10.1186/s13063-018-2485-y

Wolff, J., Nivorozhkin, A., \& Bernhard, S. (2016). You can go your own way! The long-term effectiveness of a self-employment programme for welfare recipients in Germany. International Journal of Social Welfare, 25(2), 136-148.

Zhao, H., \& Seibert, S. E. (2006). The Big Five personality dimensions and entrepreneurial status: A meta-analytical review. Journal of Applied Psychology, 91(2), 259-271. doi:10.1037/00219010.91.2.259

Zhao, H., Seibert, S. E., \& Hills, G. E. (2005). The mediating role of self-efficacy in the development of entrepreneurial intentions. Journal of Applied Psychology, 90(6), 1265-1272. doi:10.1037/00219010.90.6.1265

Zhao, H., Seibert, S. E., \& Lumpkin, G. T. (2010). The relationship of personality to entrepreneurial intentions and performance: A meta-analytic review. Journal of Management, 36(2), 381-404. doi:10.1177/0149206309335187

Zhao, X., \& You, X. (2019). The impact of psychological capital on vocational well-being: The mediation effect of emotional labor and its invariance across ethnicities. Current Psychology, 1-11. doi:10.1007/s12144-019-00287-w

Zhou, M., Zhou, Y., Zhang, J., Obschonka, M., \& Silbereisen, R. K. (2019). Person-city personality fit and entrepreneurial success: An explorative study in China. International Journal of Psychology, 54(2), 155-163. doi:10.1002/ijop.12451

Zimbardo, P. G., \& Boyd, J. N. (1999). Putting time in perspective: A valid, reliable individualdifferences metric. Journal of Personality and Social Psychology, 77, 1271-1288. 